\title{
MORPHOMETRY OF ARTICULAR FACETS OF TIBIA IN TELANGANA POPULATION
}

\section{R. Jitendra ${ }^{1}$, D.Chandrashekhar ${ }^{* 2}$, V. Janaki ${ }^{3}$.}

${ }^{1}$ Associate Professor, Department of Anatomy, Government Medical College, Nalgonda,Telangana State, India.

${ }^{* 2}$ Assistant Professor, Department of Anatomy, Government Medical College, Nizamabad, Telangana State,India.

${ }^{3}$ Associate Professor, Department of Anatomy, Kakatiya Medical College, Warangal. Telangana State, India.

\section{ABSTRACT}

Introduction:The aim of this study was to determine the morphometry of articular facets of tibia in Telangana population. The knee transplant has become a common surgery nowadays. Hence, there has risen the need for accurate tibial plateau morphometry which is population specific. The data of which will be helpful in designing population specific tibial prostheses.

Materials and Methods: The study was done on 50 adult human tibia (24 right and 26 left) collected from Department of Anatomy, Kakatiya Medical College, Warangal Telangana state. The Maximum Antero-Posterior diameter (MAPD) and maximum transverse diameter (MTD) of medial and lateral tibial condyles were measured by verniercalliper. The results were compared with other studies .

Results: The mean length and breadth of medial tibial plateau ( \pm standard deviation) is $42.7 \pm 4.1 \mathrm{~mm}$ and $30.8 \pm 2.8 \mathrm{~mm}$ and that of lateral tibial plateau is $37.5 \pm 3.9 \mathrm{~mm}$ and $30.61 \pm 3.6 \mathrm{~mm}$. The length as well as the breadth dimensions of lateral tibial plateau is less than that of medial. The length of medial tibial plateau is longer on the left side. results were compared with other population.

Conclusion: These findings in our study may assist the concerned medical persons in designing meniscal implants and tibial prostheses suitable for local population.

KEY WORDS:articular facets of tibia, Knee transplant, Tibial plateau, Maximum Antero-Posterior diameter (MAPD).

Corresponding Author: Dr.D.Chandrashekhar, Assistant Professor, Department of Anatomy, Government Medical College, Nizamabad. Telangana State, India. mobile number- 9000737570 E-Mail: dr.csdeshmukh@gmail.com

Access this Article online

Quick Response code

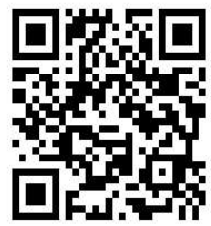

DOI: $10.16965 /$ ijar.2020.170

Journal Information

International Journal of Anatomy and Research

RG Journal ISSN (E) 2321-4287 | ISSN (P) 2321-8967

Impact: 0.21* https://www.ijmhr.org/ijar.htm

DOI-Prefix: https://dx.doi.org/10.16965/ijar

(cc) $\mathrm{Br}-\mathrm{kr}-\mathrm{sh}$

\section{Article Information}

Received: 28 May 2020

Peer Review: 29 May 2020

Revised: None
Accepted: 19 Jun 2020

Published (0): 05 Jul 2020

Published (P): 05 Jul 2020

\section{INTRODUCTION}

The knowledge of the morphometric values of tibia segments is important in Forensic, Anatomic and Archaeological studiesin order to identify unknown bodies and stature. The knee transplant has become a common surgery nowadays. Hence, there has arisen the need for accurate tibial plateau morphometry which is population specific. The data of which will be helpful in designing population specific tibial prostheses.

The tibial plateau is the superior surface of the upper end of the tibia. The intercondylar eminence is the middle elevated area of the 
tibial plateau. The intercondylar area gives attachment to the anterior and posterior attachments of the medial and lateral menisci and the cruciate ligaments. It separates the medial and lateral articulating surfaces of the tibia. These articulating surfaces of tibial plateau articulate with the articulating surfaces of the femoral condyles and in addition patellar articular surface joins them to form the knee joint. The total or partial knee replacement surgery involves resecting the superior surface of the tibia up to nearly one centimeter and replacing the resected part with the tibial prosthesis and its implantation. The knee replacement surgery is the treatment of choice in severe osteoarthritis.So the present study was undertaken to evaluate the morphometry of dried tibiae and to use the obtained osteometric data to estimate the bilateral differences between the right and the left bones.

\section{MATERIALS AND METHODS}

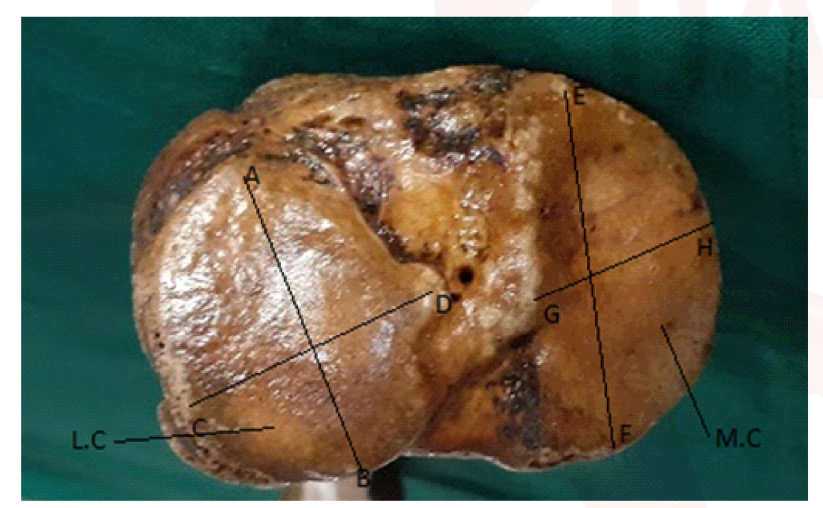

Fig. 1: Showing measuring both medial and lateral condyles of Right Tibia.

The study was conducted on a sample of 50 adult human Tibiae of unknown sex (24 right and 26 left) collected from Department of Anatomy, Kakatiya Medical College, warangal, and Government medical college of Nalgonda Telangana. Tibia with gross deformities and damaged articular surfaces are excluded from the study. The side of each bone was determined. Bones were documented with number.The length and breadth of medial and lateral tibial plateaus were measured with Vernier callipers. The length was measured from anterior end to posterior end of plateau at the point of maximum length. The breadth was measured from the intercondylar eminence of respective side to the corresponding medial and lateral end, at the midpoint
[Fig-1]. Instruments Used for the study were Digital Vernier Caliper and measuring Tape.

The following measurements were taken on all articular facets (medial \& lateral)of all Tibiae using a verniercaliper and tape:

1. maximum transverse diameter (MTD),

2. maximum antero-posterior diameter (MAPD).

All the observations and results were tabulated and compared with previously reported studies (Figure 1).

\section{RESULTS}

The medial and lateral condylar surfaces of tibia are not similar. The medial condylar plateau is oval in shape and is longer whereas lateral condylar plateau is circular $[1,2]$. Hence, tibial plateau morphometry is required for performing knee transplantation surgery. Servien E et al., opines that in vivo dimension of each tibial plateau is the key factor in planning unicompartmental knee arthroplasty and optimal coverage of resected tibial plateau is the important factor in the total knee arthroplasty $[3,4]$. The anatomical studies on tibial plateau are infrequent and very few are available in respect of South Indian population. The tibial plateau morphometric data as well as sex differences are important in the designing tibial prosthesis suitable for a local population. A mismatch can result in severe complications like cruciate ligament rupture, soft tissue misbalancing, less movements of knee joint after surgery and even prosthesis loosening [4,5].

The knee prosthesis made according to morphometric data of femur and tibia and according to the gender parameters will give excellent results and early mobility of patients as well as lesser complications after surgery $[6,7]$.

The length of medial tibial plateau was greater than the lateral. The breadth of the medial tibial plateau was also slightly more than that of lateral on the Right side. It was observed in the left sided tibiae that the average length and breadth of medial tibial plateau was greater than the Left lateral tibial plateau. On overall all the measurements are greater on the right sided tibiae when compared to left side (Table 1 \& Table 2). 
Table 1: Morphometric measurements of Tibia.

\begin{tabular}{|c|c|c|c|c|c|c|c|c|}
\hline & Right & & & & Left & & & \\
\hline s.no & $\begin{array}{l}\text { Length- Medial } \\
\text { Plateau (in } \mathrm{mm} \text { ) }\end{array}$ & $\begin{array}{l}\text { Breadth Medial } \\
\text { Plateau (in } \mathrm{mm} \text { ) }\end{array}$ & $\begin{array}{l}\text { Length- Lateral } \\
\text { Plateau (in } \mathrm{mm} \text { ) }\end{array}$ & $\begin{array}{l}\text { Breadth Lateral } \\
\text { Plateau (in mm) }\end{array}$ & $\begin{array}{l}\text { Length- Medial } \\
\text { Plateau (in } \mathrm{mm} \text { ) }\end{array}$ & $\begin{array}{l}\text { Breadth Medial } \\
\text { Plateau (in } \mathrm{mm} \text { ) }\end{array}$ & $\begin{array}{l}\text { Length- Lateral } \\
\text { Plateau (in } \mathrm{mm} \text { ) }\end{array}$ & $\begin{array}{l}\text { Breadth Lateral } \\
\text { Plateau (in } \mathrm{mm} \text { ) }\end{array}$ \\
\hline 1 & 48 & 30 & 40 & 28 & 40 & 30 & 34 & 24 \\
\hline 2 & 42 & 28 & 36 & 26 & 44 & 32 & 38 & 28 \\
\hline 3 & 46 & 30 & 40 & 28 & 36 & 22 & 32 & 20 \\
\hline 4 & 32 & 26 & 30 & 26 & 40 & 30 & 34 & 30 \\
\hline 5 & 38 & 26 & 35 & 26 & 36 & 26 & 30 & 20 \\
\hline 6 & 38 & 24 & 36 & 24 & 40 & 30 & 36 & 28 \\
\hline 7 & 38 & 26 & 32 & 22 & 40 & 32 & 36 & 30 \\
\hline 8 & 44 & 30 & 42 & 28 & 44 & 30 & 38 & 28 \\
\hline 9 & 42 & 32 & 38 & 30 & 36 & 28 & 30 & 22 \\
\hline 10 & 42 & 30 & 40 & 30 & 40 & 28 & 34 & 28 \\
\hline 11 & 42 & 30 & 34 & 30 & 44 & 28 & 30 & 24 \\
\hline 12 & 38 & 32 & 34 & 30 & 40 & 30 & 36 & 26 \\
\hline 13 & 42 & 32 & 38 & 28 & 38 & 26 & 36 & 24 \\
\hline 14 & 40 & 28 & 36 & 26 & 34 & 24 & 28 & 22 \\
\hline 15 & 40 & 24 & 38 & 22 & 44 & 30 & 38 & 30 \\
\hline 16 & 30 & 28 & 34 & 26 & 40 & 30 & 40 & 30 \\
\hline 17 & 40 & 28 & 36 & 26 & 36 & 26 & 36 & 26 \\
\hline 18 & 42 & 32 & 38 & 28 & 44 & 32 & 38 & 30 \\
\hline 19 & 42 & 30 & 36 & 30 & 40 & 28 & 32 & 24 \\
\hline 20 & 36 & 26 & 32 & 24 & 36 & 26 & 34 & 28 \\
\hline 21 & 42 & 28 & 38 & 26 & 38 & 26 & 30 & 24 \\
\hline 22 & 34 & 26 & 32 & 22 & 40 & 30 & 40 & 30 \\
\hline 23 & 38 & 26 & 36 & 24 & 38 & 28 & 36 & 26 \\
\hline 24 & 40 & 30 & 36 & 26 & 38 & 28 & 36 & 26 \\
\hline 25 & & & & & 38 & 28 & 36 & 26 \\
\hline 26 & & & & & 40 & 30 & 36 & 26 \\
\hline Total mean & 39.83 & 28.41 & 36.12 & 27.5 & 39.38 & 28.38 & 34.76 & 26.15 \\
\hline
\end{tabular}

Table 2: Morphometric measurements of Tibia.

\begin{tabular}{|cccc|}
\hline Parameters & right/left & Measurement & mean \\
\hline $\begin{array}{c}\text { Anterior Posterior } \\
\text { Diameter }\end{array}$ & Right & Medial & 39.83 \\
\hline & & Lateral & 36.12 \\
\hline Transverse Diameter & Right & Medial & 28.41 \\
\hline & & Lateral & 27.5 \\
\hline $\begin{array}{c}\text { Anterior Posterior } \\
\text { Diameter }\end{array}$ & Left & Medial & 39.38 \\
\hline & & Lateral & 34.76 \\
\hline Transverse Diameter & Left & Medial & 28.38 \\
\hline & & Lateral & 26.15 \\
\hline
\end{tabular}

\section{DISCUSSION}

The geometry and anatomy of the knee is variable, irrespective of gender and the human race and it should be considered carefully during the design process of the tibia prosthesis for the Total Knee Arthroplasty (TKA).

In the present study the length of medial tibial plateau is greater than the lateral. The breadth of the medial tibial plateau was also slightly more than that of lateral on both sides and Rightsided measurements are little longer than left side measurements. The morphometry depends on the stature of the population. Asians have smaller stature compared to the western population. The knee prosthesis available in the market may not match with the morphometry of Indian population. Indian patients are at the risk of getting a prosthesis which is oversized in procedures like uni-compartmental knee arthroplasty and total knee arthroplasty. Over-sized knee prosthesis can lead to incompatibility with the resected bones. Studies in indian population Swathi et al. (2014) (7) found the mean AP diameter and transeverse diameter of medial and lateral condyle on right side as $4.84 \mathrm{~cm} \& 3.01 \mathrm{~cm}$ and $4.23 \mathrm{~cm} \& 2.72 \mathrm{~cm}$, they found the mean transverse, AP diameter of medial and lateral condyle on the left side as $2.92,4.72 \mathrm{~cm}$ and $2.89,4.03 \mathrm{~cm}$. Our study gives morphometry of tibial plateau similar to North Indian study mentioned[8].

Srivastava et al. found the mean AP diameter and transverse diameter of medial and lateral condyle on right side as $3.86 \mathrm{~cm} \& 2.97 \mathrm{~cm}$ and $3.64 \mathrm{~cm} \& 2.92 \mathrm{~cm}$, They found the mean transverse, AP diameter of medial and lateral condyle on the left side as $2.75,3.99 \mathrm{~cm}$ and $2.97,3.69 \mathrm{~cm}$. While in our study, we got the values as $3.98,2.8 \mathrm{~cm}$ and $3.62,2.75$ on the right side and $2.75,3.93 \mathrm{~cm}$ and $2.83,3.47 \mathrm{~cm}$ on the left side, strongly correlating with parameters of this author.

Muralimanju BV et al. (2016) [9], found the mean AP diameter and transverse diameter of medial 
Table 3: Morphometric measurements of Tibia in various authors.

\begin{tabular}{|c|c|c|c|c|c|c|c|c|}
\hline Study and year & Right & & & & Left & & & \\
\hline & $\begin{array}{l}\text { Length Medial } \\
\text { Plateau (in mm) }\end{array}$ & $\begin{array}{l}\text { Breadth Medial } \\
\text { Plateau (in } \mathrm{mm} \text { ) }\end{array}$ & $\begin{array}{l}\text { Length Lateral } \\
\text { Plateau (in } \mathrm{mm} \text { ) }\end{array}$ & $\begin{array}{l}\text { Breadth Lateral } \\
\text { Plateau (in } \mathrm{mm} \text { ) }\end{array}$ & $\begin{array}{l}\text { Length Medial } \\
\text { Plateau (in } \mathrm{mm} \text { ) }\end{array}$ & $\begin{array}{l}\text { Breadth Medial } \\
\text { Plateau (in } \mathrm{mm} \text { ) }\end{array}$ & $\begin{array}{l}\text { Length Lateral } \\
\text { Plateau (in } \mathrm{mm} \text { ) }\end{array}$ & $\begin{array}{l}\text { Breadth Lateral } \\
\text { Plateau (in } \mathrm{mm} \text { ) }\end{array}$ \\
\hline Swathi et al. (2014) (7) & $48.45 \pm 4.4$ & $30.18 \pm 2.83$ & $42.39 \pm 4.19$ & $27.25 \pm 3.05$ & $47.23 \pm 4.32$ & $29.28 \pm 3.14$ & $40.36 \pm 4.65$ & $28.91+3.02$ \\
\hline Srivastava A et al. (2014) (8) & 38.63 & 29.73 & 36.47 & 29.21 & 39.94 & 27.5 & 36.94 & 29.77 \\
\hline Muralimanju BV et al. (2016) [9] & $40.6 \pm 3.9$ & $26.9 \pm 2$. & $34.8 \pm 3.7$ & $26.5 \pm 3.4$ & $39.2 \pm 3.6$ & $26.6 \pm 2.7$ & $32.6 \pm 3.4$ & $25.7 \pm 2.5$ \\
\hline Ugochukwu EG et al. (2016) [10] & $46.1 \pm 5.1$ & $30.3 \pm 4.3$ & $48.0 \pm 5.1$ & $29.6 \pm 4.1$ & $45.1 \pm 3.1$ & $31.5 \pm 4.1$ & $49.2 \pm 2.4$ & $31.3 \pm 2.4$ \\
\hline Prasanna Veera Kumar Attada et al (2018) (11) & $41.4 \pm 3.2$ & $30.7 \pm 3.2$ & $37.9 \pm 4.4$ & $30.5 \pm 3.4$ & $44.1 \pm 4.5$ & $30.9 \pm 2.4$ & $37.0 \pm 3.5$ & $30.72 \pm 3.9$ \\
\hline Present study 2020 & 39.83 & 28.41 & 36.12 & 27.5 & 39.38 & 28.38 & 34.76 & 26.15 \\
\hline
\end{tabular}

and lateral condyle on right side as $4.06 \mathrm{~cm} \&$ surgeries which require optimum prosthesis $2.69 \mathrm{~cm}$ and $3.48 \mathrm{~cm} \& 2.65 \mathrm{~cm}$, they found the mean transverse, AP diameter of medial and lateral condyle on the left side as $2.66,3.92 \mathrm{~cm}$ and $2.57,3.26 \mathrm{~cm}$.

Ugochukwu EG et al. (2016) [10]. found the mean AP diameter and transverse diameter of medial and lateral condyle on right side as 4.61 $\mathrm{cm} \& 3.03 \mathrm{~cm}$ and $4.80 \mathrm{~cm} \& 2.96 \mathrm{~cm}$, They found the mean transverse, AP diameter of medial and lateral condyle on the left side as $3.15,4.51 \mathrm{~cm}$ and $3.13,4.92 \mathrm{~cm}$.

Prasanna Veera Kumar Attada et al (2018) (11) et al. found the mean AP diameter and transverse diameter of medial and lateral condyle on right side as $4.14 \mathrm{~cm} \& 3.07 \mathrm{~cm}$ and $3.79 \mathrm{~cm} \&$ $3.05 \mathrm{~cm}$, They found the mean transverse, AP diameter of medial and lateral condyle on the left side as $3.09,4.41 \mathrm{~cm}$ and $3.07,3.72 \mathrm{~cm}$.

With the above comparison we can conclude that there is no significant difference in the morphometric parameters of the tibial plateau among the North and South Indian populations. But significant differences exist with other authors with respect to most of the parameters. it was observed that the lateral tibial plateau is smaller than the medial one; therefore the need was highlighted for a knee arthroplasty procedure which takes into account the difference to ensure complete tibial coverage. The lateral tibial plateau would need a different tibial implant, round in shape and with a smaller length and breadth. In the surgical practice, the orthopaedists avoid implants with incomplete coverage of the tibia as this may induce the collapse of the implant. Hence, the implant designing needs knowledge of the size of the tibial plateau. The morphology of the tibial prosthetic component should match the resected surface in order to restore the stability and load transmission after knee replacement. Total Knee Arthroplasty (TKA) and uni-compartmental knee arthroplasty are both accurate sizing. This is important to ensure a better prognosis and prosthesis long term survival, which would lead to normal function post operatively.

Moghtadaei $\mathrm{M}$ et al., in their CT scan study of knee joints observed that besides precise surgical techniques in TKA, proper sizing of the prosthesis is mandatory for a successful and long-life outcome. Any mismatch in the form of overhanging or under sizing of the components can lead to altered soft-tissue tensioning and impaired patello-femoral tracking. They further observed that in order to enhance the quality of the fitness yielded by prostheses, morphometric studies from diverse ethnicities are mandatory. They stated that as the Asian populations have smaller knee compared with Caucasians, there is need for alteration in sizing and configuration of current prostheses to best fit them. They further mentioned that anthropometric surveys from China, Korea, Japan, India, Malaysia and Thailand were conducted to construct Asian knee profile. But, there were delicate discrepancies in methodology and results of these studies that can affect the outcome of TKA in a different manner from Western population.

\section{CONCLUSION}

The knowledge of the morphometric values of tibia segments is important in Forensic, Anatomic and Archeological cases in order to identify unknown bodies and stature. Therefore our study supplies the mean values of the different morphometric measurements from the tibia. As a result, these measurements may help to indicate the characteristic morphological features of tibial segments in our population and also help the Orthopedic surgeon to place the various implants in the reconstruction of tibial fractures and other pathological conditions of knee. 


\section{Conflicts of Interests: None}

\section{REFERENCES}

[1]. Gray's Anatomy. The Anatomical Basis of Clinical Practice. 39th Edition, Elsevier Churchill Livingstone.2005. Pp:1436-37.

[2]. Servien E, Saffarini M, Lustig S, Chomel S, Neyret P. Lateral versus medial tibial plateau: morphometric analysis and adaptability with current tibial component design. Knee Surg Sports TraumatolArthrosc. 2008;16(12):1141-45.https://doi.org/10.1007/ s00167-008-0620-0. PMid:18779949

[3]. Murshed KA, Cicekcibasi AE, Karabacakoglu A, Seker $M$, Ziylan T. Distal femur morphometry: a gender and bilateral comparative study using magnetic resonance imaging. Surg Radiol Anat. 2005;27(2):108-12.https://doi.org/10.1007/s00276004-0295-2PMid:15580343

[4]. Anderson AF, Dome DC, Gautam S, Awh MH, Rennirt GW. Correlation of anthropometric measurements, strength, anterior cruciate ligament size and intercondylar notch characteristics to sex differences in anterior cruciate ligament tear rates. Am J Sports Med. 2001;29(1):58-66.https://doi.org/10.1177/ 03635465010290011501PMid:11206258

[5]. Terzidis I, Totlis T, Papathanasiou E, SideridisA,Vlasis K, Natsis K. Gender and Side-to-Side Differences of Femoral Condyles Morphology: Osteometric Data from 360 Caucasian Dried Femori. Anatomy Research International. vol. 2012, Article ID 679658, 6 pages, 2012.https://doi.org/10.1155/2012/ 679658PMid:22970374 PMCid:PMC3437276

[6]. Cheng FB, Ji XF, Lai Y, Feng JC, Zheng WX, Sun YF, et al. Three dimensional morphometry of the knee to design the total knee arthroplasty for Chinese population. Knee. 2009;16(5):341-47.https://doi.org/ 10.1016/j.knee.2008.12.019PMid:19230678
[7]. Swathi Gandhi, Rajankumar Singla, Jagadev singhkullar, Rajesh kumarsuri and Vandana Mehta. Morphometric analysis of upper end of tibia JCDR 2014 Aug : 8(8): AC 10 -AC https://doi.org/10.7860/ JCDR/2014/8973.4736PMid:25302182 PMCid:PMC4190701

[8]. Srivastava A, Yadav A, Thomas RJ, Gupta N. Morphometric study of tibial condylar area in the North Indian population. J Med Sci Clin Res. 2014;2:51519.

[9]. Murlimanju BV, Purushothama C, Srivastava A, Kumar CG, Krishnamurthy A, Blossom V, et al. Anatomical morphometry of the tibial plateau in South Indian Population. Italian Journal of Anatomy and Embyology. 2016;121(3):258-64.

[10]. Ugochukwu EG, Ugbem LP, ljomone OM, Ebi OT. Estimation of Maximum Tibia Length from its Measured Anthropometric Parameters in a Nigerian Population. J Forensic Sci Med. 2016; 2:222-28.https:// doi.org/10.4103/2349-5014.197928

[11]. Prasanna Veera Kumar Attada et al. Tibial Plateau Morphometry in South Indian Population. International Journal of Anatomy, Radiology and Surgery. 2018;7(3): AO18-AO22

[12]. Moghtadaei M, Moghimi J, Farahini H, Jahansouz A. Morphology of proximal tibia in Iranian populationand its correlation with available prostheses. Med J Islam Repub Iran. 2015;29: 225-31

How to cite this article:

R. Jitendra, D.Chandrashekhar, V. Janaki. MORPHOMETRY OF ARTICULAR

FACETS OF TIBIA IN TELANGANA POPULATION. Int J Anat Res 2020;8(3.1):7594-7598. DOI: 10.16965/ijar.2020.170 